San Jose State University

SJSU ScholarWorks

Master's Theses

Master's Theses and Graduate Research

1992

\title{
A comparison of food resources available to the valley pocket gopher, Thomomys bottae, on serpentine and nonserpentine soils
}

Nadine Christena Barter Bowlus

San Jose State University

Follow this and additional works at: https://scholarworks.sjsu.edu/etd_theses

\section{Recommended Citation}

Barter Bowlus, Nadine Christena, "A comparison of food resources available to the valley pocket gopher, Thomomys bottae, on serpentine and nonserpentine soils" (1992). Master's Theses. 448.

DOI: https://doi.org/10.31979/etd.s793-9pu7

https://scholarworks.sjsu.edu/etd_theses/448

This Thesis is brought to you for free and open access by the Master's Theses and Graduate Research at SJSU ScholarWorks. It has been accepted for inclusion in Master's Theses by an authorized administrator of SJSU ScholarWorks. For more information, please contact scholarworks@sjsu.edu. 


\section{INFORMATION TO USERS}

This manuscript has been reproduced from the microfilm master. UMI films the text directly from the original or copy submitted. Thus, some thesis and dissertation copies are in typewriter face, while others may be from any type of computer printer.

The quality of this reproduction is dependent upon the quality of the copy submitted. Broken or indistinct print, colored or poor quality illustrations and photographs, print bleedthrough, substandard margins, and improper alignment can adversely affect reproduction.

In the unlikely event that the author did not send UMI a complete manuscript and there are missing pages, these will be noted. Also, if unauthorized copyright material had to be removed, a note will indicate the deletion.

Oversize materials (e.g., maps, drawings, charts) are reproduced by sectioning the original, beginning at the upper left-hand corner and continuing from left to right in equal sections with small overlaps. Each original is also photographed in one exposure and is included in reduced form at the back of the book.

Photographs included in the original manuscript have been reproduced xerographically in this copy. Higher quality $6 "$ x 9 " black and white photographic prints are available for any photographs or illustrations appearing in this copy for an additional charge. Contact UMI directly to order.

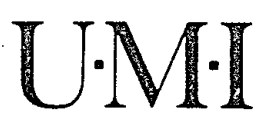

University Microfilms International

A Bell \& Howell Information Company 

Order Number 1351019

A comparison of food resources available to the valley pocket gopher, Thomomys bottae, on serpentine and nonserpentine soils

Bowlus, Nadine Christena Barter, M.A.

San Jose State University, 1992

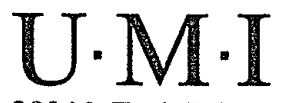

300 N. Zeeb Rd.

Ann Arbor, MI 48106 



\title{
A COMPARISON OF FOOD RESOURCES \\ AVAILABLE TO THE VALLEY POCKET GOPHER, THOMOMYS BOTTAE, ON SERPENTINE AND NONSERPENTINE SOILS
}

\author{
A Thesis \\ Presented to \\ The Faculty of the Department of Biological Sciences \\ San Jose State University \\ In Partial Fulfillment \\ of the Requirements for the Degree \\ Master of Arts
}

By

Nadine Christena Barter Bowlus

December, 1992 
APPROVED FOR THE DEPARTMENT OF BIOLOGICAL SCIENCES

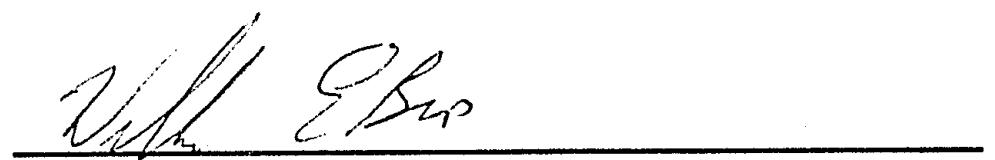

Dr. William E. Bros

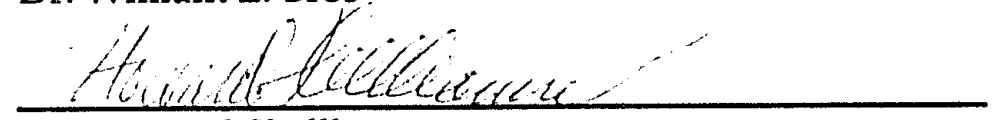

Dr. Howard Shellhammer

Tf

W

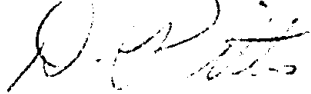

Dr. Wanna Pitts

APPROVED FOR THE UNIVERSITY

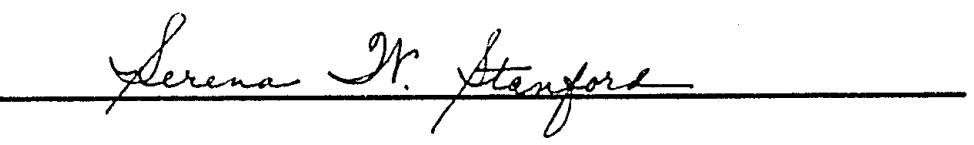




\section{ABSTRACT \\ A COMPARISON OF FOOD RESOURCES \\ AVAILABLE TO THE VALLEY POCKET GOPHER, THOMOMYS BOTTAE, ON SERPENTINE AND NONSERPENTINE SOILS}

\section{By Nadine Christena Barter Bowlus}

Pocket gophers (Thomomys bottae) living in grasslands growing on serpentine soils may be exposed to food resources that differ from those that grow on nonserpentine soils. Plant responses to different chemical and physical conditions may provide diets for pocket gophers that differ in plant biomass, amount and distribution of macronutrients in plant tissues, or distribution of ground cover. This study used a block factorial design to compare serpentine and nonserpentine food resources for such differences.

Although plant chemistry was found to correlate strongly with soil chemistry, differences in plant chemistry were mainly the result of geographic location. Differences in biomass between soil types were small or nonexistent. Distribution of cover was determined by interactions between cover type and both geographic location and soil type. Geographic variation was strong enough that the question of food resource differences caused by soil type could not be resolved. 
For my parents, LeRoy and Isabel Barter 


\section{ACKNOWLEDGEMENTS}

No investigator works alone; thus, it is appropriate to acknowledge here those people who helped with this study. First, my deepest appreciation goes to my husband, Stephen, for his personal and financial support. Secondly, special thanks are due to my sons, Russell and Timothy, for their help in the field and forbearance at home. Other members of my "field crew" were Carolyn Warren and Charles Franklin, to whom I also offer my thanks. Dr. William E. Bros patiently guided the design and accomplishment of the study. To him, my thanks for his help both as teacher and as colleague. The other members of my committee, Dr. Wanna Pitts and Dr. Howard Shellhammer, contributed their encouragement and advice along the way, and gentle prodding as deadlines approached. 


\section{TABLE OF CONTENTS}

$\begin{array}{lr}\text { ABSTRACT } & \text { iii } \\ \text { ACKNOWLEDGEMENTS } & \mathrm{v} \\ \text { TABLE OF CONTENTS } & \text { vi } \\ \text { LIST OF TABLES } & \text { vii } \\ \text { LIST OF FIGURES } & \text { viii } \\ \text { INTRODUCTION } & 1 \\ \text { MATERIALS AND METHODS } & 6 \\ \text { RESULTS } & 13 \\ \quad \text { Soil chemistry versus plant chemistry } & 19 \\ \quad \text { Biomass comparison } & 21 \\ \quad \text { Selective foraging } & 21 \\ \text { Comparisons of plant chemistry } & 29 \\ \text { CITERATURE CITED } & 34\end{array}$




\section{LIST OF TABLES}

Table 1: Canonical correlations and canonical loadings for comparisons of plant chemistry with soil chemistry. Loadings $\leq 0.3$ were not interpreted.

Table 2. Two-way ANOVA for soil type versus plant tissue location using ranked biomass. Park sampled is a block factor. Soil type levels are serpentine and nonserpentine. Tissue location levels are above- and belowground. Parks were Edgewood Park and Santa Teresa Park.

Table 3. Two-way ANOVAs for individual plant categories. The factors were soil type versus tunnel sample with park as a block. Data are ranked biomass. Soil type levels are serpentine and nonserpentine. Tunnel levels are tunnel sample and nontunnel sample. Parks were Edgewood Park and Santa Teresa Park.

Table 4. Two-way ANOVAs for plant macronutrients. Data are arcsine transformed percent dry weight. Factors are soil type versus plant tissue location with park as a block factor.

Table 5. Two-Way ANOVA for cover type versus soil type with park as a block using ranked percent cover. Cover type levels were grass, dicot, bare ground, rock, and gopher mound. Soil type levels were serpentine and nonserpentine. Parks sampled were Edgewood Park and Santa Teresa Park.

Table 6. One-Way ANOVAs for soil type with park as a block. Data are Pielou's J' and number of cover patches. Soil type levels are serpentine and nonserpentine. Parks sampled were Edgewood Park and Santa Teresa Park. 


\section{LIST OF FIGURES}

Figure 1: First significant canonical pairs comparing aboveground plant chemistry with soil chemistry for nonserpentine and serpentine soil types. $\mathrm{E}=$ Edgewood Park; $\mathrm{S}=$ Santa Teresa Park.

Figure 2. First significant canonical pairs comparing belowground plant chemistry with soil chemistry for nonserpentine and serpentine soil types. $\mathrm{E}=$ Edgewood Park; $\mathrm{S}=$ Santa Teresa Park.

Figure 3. Dicot biomass: mean ranks for tunnel versus nontunnel samples.

Figure 4. Plant calcium: comparison of mean ranks for significant threeway interaction, Soil * Location * Park. Soil type levels are serpentine and nonserpentine. Plant tissue location levels are above- and belowground. Park sampled was a block and included Edgewood Park and Santa Teresa Park.

Figure 5. Plant calcium: comparison of mean ranks for significant threeway interaction, Soil * Location * Park. Soil type levels are serpentine and nonserpentine. Plant tissue location levels are above- and belowground. Park sampled was a block and included Edgewood Park and Santa Teresa Park.

Figure 6. Plant nitrogen: mean ranks for plant tissues located aboveground versus belowground tissues.

Figure 7. Percent Cover: mean ranks for significant Cover Type * Soil interaction. Cover type levels are grass, dicot, bare ground, rock, and gopher mound. Soil type levels are serpentine and nonserpentine.

Figure 8. Percent Cover: mean ranks for significant Cover Type * Park interaction. Cover type levels are grass, dicot, bare ground, rock, and gopher mound. Parks sampled were Edgewood Park and Santa Teresa Park. 


\section{INTRODUCTION}

Pocket gophers (Thomomys bottae) residing in serpentine soils may be presented with an unusual mix of nutrients in their diet. This proposal was based on the known chemical peculiarities of serpentine soils, the responses of plants that grow on these soils, and the presence of pocket gophers as herbivores in these habitats (Proctor and Whitten, 1971). "Serpentine" as used here refers to a class of metamorphosed ultramafic rocks containing serpentinitic minerals and the soils derived from them. Relative to other soils, serpentine soils have low quantities of nitrogen, phosphorus, potassium; low calcium; high magnesium; low molybdenum; and relatively high nickel and chromium. In addition, the soils tend to be stony and shallow, and unstable when found on slopes (Kruckeberg, 1984).

Vegetation in serpentine soils is physiognomically different from the nearby vegetation in other soil types. Plants growing on serpentine soils exhibit "serpentine syndrome" characterized by xeromorphic foliage, stunted growth forms, and increases in the root system (Kruckeberg, 1984). High levels of magnesium affect calcium uptake by plants by competing for binding sites. The relationship between soil calcium and magnesium has been investigated as a probable cause of serpentine syndrome (Proctor and Woodell, 1975).

Kruckeberg (1984) suggests that the interactions among soil ions, temperature, moisture, a xeric microclimate, and the responses that plants make to these factors all work together to establish and maintain the classic serpentine syndrome. 
Plants use a combination of strategies to cope with serpentine soil chemistry and this leads to plant assemblages with varied chemical composition (Kruckeberg, 1984). Plant responses to high magnesium levels include sequestration in roots, restricting uptake beyond the roots, or active exclusion from any tissue. Plants may cope with low calcium levels by absorbing that cation preferentially. No one strategy is common to all plants growing in serpentine soil, and plants may utilize a combination of strategies (Kruckeberg, 1984). Proctor and Whitten's (1971) suggestion that pocket gopher diets might differ on serpentine soils as compared to diets on nonserpentine soils is based on the assumption that plant chemistry reflects soil chemistry.

Herbivores, including pocket gophers, who forage on serpentine plants may use selective foraging to avoid excess nutrients and to balance nutrient intake. Several authors have shown that pocket gophers do feed selectively among plant varieties (Gettinger, 1984b; Hunt, 1989; Williams and Cameron, 1986). In general, pocket gophers have two different kinds of choices, among plant species and among plant parts. Plant diversity holds the potential for diversity in chemical composition, as noted above. Plant diversity on serpentine soils is often higher than on surrounding nonserpentine soils because of the presence of species endemic to serpentine and serpentine ecotypes of wideranging species (Walker, 1954). Therefore, selective foraging may be a profitable strategy on serpentine soils. In addition, if above- and belowground parts of plants differ in chemistry, pocket gophers could choose among plant parts. Although pocket gophers are usually characterized as feeding primarily on belowground plant parts, Gettinger (1984b) and Hunt (1989) have shown that at least one species, Thomomys bottae makes extensive use of aboveground plant 
material in its diet. Unfortunately, very little is known about the relative differences in chemistry between above- and belowground portions of plants.

Lowered primary productivity has been noted as a feature of plants growing on serpentine soils in many studies (Kruckeberg, 1954; Whittaker, 1954). If serpentine soils in general support fewer, smaller plants, then the amount of food resources available to an herbivore would be different on serpentine than on nonserpentine soil. In addition, the available biomass may be partitioned differently among above- and belowground plant parts. As noted earlier, serpentine plants have larger root systems than conspecifics growing in nonserpentine soils (Kruckeberg, 1984). If the supply of bulbs, corms, and succulent roots is more abundant in one soil type, then a belowground forager would find more food in that soil type. Proctor and Whitten (1971) felt that this was the case for the serpentine grassland that they studied. Because pocket gophers use a very energy intensive foraging method, having less food available increases the energy cost per calorie (Bunnell and Harestad, 1990). Thus, if serpentine habitats differ from nonserpentine habitats in terms of available food biomass, there could be a resulting difference in the energy cost of harvesting food resources between the two habitat types.

If the chemistry of plants growing on serpentine soil differs from the plant chemistry of nonserpentine plants, then the amount and the balance of nutrients available to herbivores would differ between the two habitats. Food resources on serpentine soils may be different because they provide lower amounts of nutrients than those on nonserpentine soils. This effect may be partly the result of lower biomass, but also the result of imbalances among the nutrients resulting 
from the soil chemistry. As noted above, the excess magnesium in serpentine soils is handled differently by different plant species. Proctor and Whitten (1971) noted Brodiaea corms with high magnesium levels. The nutritional quality of available food resources has been shown to affect the growth of pocket gophers (Patton and Brylski, 1987).

Selective foraging is a useful strategy only in those habitats that offer a variety of possible food choices. The species composition of grasslands on serpentine is often different from nonserpentine grasslands. The severe physical and chemical conditions on serpentine soils more strongly affect introduced plants than native plants that have had the time to become adapted or to have developed tolerant ecotypes. Thus serpentine grasslands are often refugia for native forbs and grasses (Huenneke, et al., 1990; Proctor and Woodell, 1975; Walker, 1954). The greater variety of plants found in serpentine grasslands should afford pocket gophers greater opportunities for selective foraging to achieve a balanced diet.

The present study was done to test the assumption that plant resources on serpentine soils provide a diet for pocket gophers that could be considered different compared to food resources from nonserpentine soils. Differences in food resources could arise in different ways as noted in the discussion above. Questions addressed with this study considered each of three possible sources of difference. Specifically, does food resource biomass differ among soil types or plant parts? Does food resource chemistry differ among soil types? And does the variety of the food resources differ among soil types? 
The chemistry of plants growing on serpentine soils has shown a close correlation to soil chemistry, but such a correlation is less clear for plants growing on nonserpentine soils (Kruckeberg, 1984; Proctor, 1971; Taiz and Zeiger, 1991). One goal of the present study was to examine the correlation between plant and soil chemistry in both serpentine and nonserpentine soils. Because belowground plant parts might track soil values more closely than aboveground parts, it is important to examine these groups separately.

Differences between the food resources produced by the two soil types could be the result of differing amounts of material available, so the biomass of food resources was compared. Differences in biomass could be the result of the sparseness of vegetation on serpentine soils, so the total biomass from each soil type was compared. Biomass differences could also be the result of the apportionment of biomass into above- and belowground plant tissues, so comparisons were also made with respect to above- or belowground location of the plant parts. Gophers may chose to maximize energy gain by eating the most abundant portions of plants. A related investigation considered the possibility of selective foraging by gophers by comparing the biomass of different plant types sampled from above gopher tunnels with the biomass of plant types sampled in neighboring nontunnel areas.

Because differences between the food resources produced by the two soil types could be the result of differences in plant chemistry, the chemical content of plants was compared. Serpentine plants have been found to reflect generally the chemistry of serpentine soil, at least for certain compounds (Proctor and Woodell, 1975). However, excess elements may be stored or sequestered 
preferentially in above- or belowground plant tissues. This sequestering would cause the chemistry of aboveground plant tissues to differ from that of belowground tissues. Differences in plant chemistry, if detectable, may guide gopher choice of plant type and above- or belowground material.

Finally, differences in plant variety could cause differences in the food resources available on the two soil types, so plant diversity was compared in terms of variety of plant types and their distribution. As noted previously, greater plant variety would increase the ability of gophers to forage selectively. A distribution of food resources that is characterized by small patches of different plant types would afford pocket gophers the possibility of finding food plants in concentrated patches, but patches of desirable foods might be relatively rare.

\section{MATERIALS AND METHODS}

The two public parks used in the study each contained serpentine and non serpentine soils, grassland vegetation, and resident populations of the Valley. Pocket Gopher (Thomomys bottae). In both parks, two study sites were selected, one for each soil type. The two parks formed the basic replicate units for the study.

The first park was Edgewood Park, San Mateo County, $\left(37^{\circ} 27^{\prime} 30^{\prime \prime} / 122^{\circ} 17^{\prime} 30^{\prime \prime}\right.$, Woodside Quadrangle). The elevations of the two study sites in the park ranged between 225 and 238 meters above sea level. The serpentine site faces east on an outcrop of a serpentine band that runs roughly east to west through the south end of the park. The nonserpentine site is on the 
west- facing side of a hill directly north of the hill containing the serpentine site. Vegetation on both study sites is dominated by grasses; however, both also contain patches of forbs. Pocket gopher burrows and unvegetated gopher mounds were present on both sites.

The second pair of study sites was in Santa Teresa County Park, Santa Clara County ( $37^{\circ} 12^{\prime} 30^{\prime \prime} / 121^{\circ} 47^{\prime} 30^{\prime \prime}$, Santa Teresa Hills Quadrangle). Serpentine and nonserpentine study sites at Santa Teresa Park were selected on the hills north and south of the picnic and equestrian area on the west side of the park. The nonserpentine site is on the hilltop north of the picnic area. Elevation at the peak of the hill is 217 meters above sea level. The serpentine site is on the north facing slope of the ridge south of the picnic area. Elevation is between 214 and 232 meters above sea level. Pocket gopher mounds and burrows were present on both soil types. Both soil types also supported colonies of California Ground Squirrel (Spermophilus beecheyi). The presence of pocket gophers was confirmed by the smaller diameter of tunnels, the characteristic shape of fresh mounds, and the live capture of at least one pocket gopher from each soil type.

Data for the study were gathered in two ways, the first of which was a series of trench samples. A trench sample consisted of all soil and plants from a rectangular plot measuring $7 \times 40 \mathrm{~cm}$, with a depth of $10-15 \mathrm{~cm}$. Preliminary sampling indicated that this size trench would provide sufficient resolution for the statistical analyses while minimizing the amount of human disturbance to the study sites. Plants from the trench samples were separated into three categories; grasses, dicots, and geophytes. All plants growing from bulbs or corms, as well as unsprouted bulbs and corms were considered geophytes. Grasses and dicots 
were separated on the basis of appearance, and for seedlings, the number of cotyledons. The number of individual plants in each category was counted and the mass of each category was determined for each trench sample from air dried material. Plants from each trench sample were then combined and divided into above- and belowground portions, dried overnight at $80^{\circ} \mathrm{C}$, and weighed for the biomass comparisons. This same material was analyzed for nitrogen, phosphorus, potassium, calcium and magnesium by a commercial laboratory. Soil from the trench samples was sieved through a $2 \mathrm{~mm}$ brass screen. The $2 \mathrm{~mm}$ fraction was dried overnight at $80^{\circ} \mathrm{C}$, weighed, and analyzed for the same five elements.

Canonical correlation analyses were used to investigate potential relationships between plant chemistry and soil chemistry. Reported values for soil chemistry were converted from parts per million to percent dry weight to correspond to the reported values for plant chemistry. The percentage data were arcsine transformed before the analysis in order to normalize the distribution. The transformed data were used for all canonical correlation procedures. Canonical loadings less than 0.3 were considered insignificant and were not included in the interpretation of canonical pairs. Four separate analyses were conducted. The first examined the relationship between aboveground plant chemistry and soil chemistry for non-serpentine soil. The second analysis used variables from the same soil type but considered belowground plant chemistry in relation to soil chemistry. The third and fourth analyses were a repetition of the first two but used data from serpentine soil sites. For this analysis, significant correlations indicate that the chemistry of plant tissues is strongly related to the soil chemistry. 
To determine if the apportionment of biomass in above- and belowground plant tissues differs among soil types, biomasses from trench samples were compared. A two-way analysis of variance (ANOVA) was used for the comparison. Soil type and above- or belowground plant tissue location were the treatment factors considered. To control for variation resulting from the different geologic and ecologic histories of the areas, the park from which the samples came was included in the analysis as a blocking factor. When considering the results of this analysis, a significant soil effect indicates that the amount of biomass available differs according to the soil type. A significant location effect indicates that the amount of biomass differs for above- or belowground plant tissues. A significant interaction between soil and location indicates that the apportionment of biomass in aboveground and belowground tissues depends on the soil type.

Possible diet preferences were assessed by taking paired trench samples from active gopher tunneling sites and adjacent non-tunnel areas. The tunnel sample consisted of the roof of an active tunnel. A second trench was dug adjacent to the active tunnel and to same depth as the tunnel roof to sample a nontunnel area. The biomass of plant material attributed to the three plant categories was compared with respect to soil type and tunnel/nontunnel location in a two-way ANOVA including the effect of park as a block. A separate analysis was done for each of the three plant categories: grass, dicot, and geophyte. For this set of analyses, a significant soil effect indicates that pocket gophers are harvesting different amounts of a plant category according to soil type. A significant tunnel effect indicates that gophers are removing a particular plant 
type from the soil. A significant interaction between soil type and tunnel location indicates that gopher choice of plant type is determined by soil type.

Differences in plant chemistry were examined using the elemental analyses of plant materials from the trench samples. The reported percent dry weight values were arcsine transformed prior to analysis, and the transformed data were used throughout. For each of the five elements, nitrogen, phosphorus, potassium, calcium, and magnesium, separate two-way ANOVAs compared soil type and above- or belowground location. Park was included as a block. Considering the results of this set of analyses, a significant soil effect means that plant chemistry differs between soil types. A significant location effect means that the chemical composition differs between above- and belowground plant tissues. A significant interaction between above- and belowground location and soil indicates that the apportionment of chemical elements between above- and belowground tissues is dependent upon soil type.

Transect samples were used to provide information about plant and ground cover at the study sites. The length of the intersection of five cover categories with a 10 meter transect line was measured to the nearest $5 \mathrm{~cm}$. Cover categories were: grasses, dicots, rocks, bare ground, and gopher mounds. If an area of unvegetated ground consisted of a solid mass greater than $5 \mathrm{~cm}$, the area was classified as rock. Areas were considered bare ground if particles were of mixed size and tightly packed together. Areas of unvegetated ground which contained loose piles of soil particles of similar size were considered gopher mounds. The placement of the 10 meter transects was determined by starting the transects in the center of one edge of a study site, and then pacing along the long 
axis of the site to start subsequent transects. The number of paces between one transect and the next and the compass direction of each transect was determined by a set of randomly generated number pairs.

Data from the transect samples were used to compare the distribution of cover types on each soil type. Amount of cover in terms of the total length of the transect intersections was compared with respect to cover type and soil type in a two-way ANOVA including the effects of park as a block. For this analysis, a significant cover effect indicates that ground cover is not apportioned equally among the cover types. A significant soil effect indicates that the representation of cover types differs according to soil type. A significant interaction between cover and soil indicates that the apportionment of ground cover among the cover categories is determined by the soil type. Individual cover types were also examined separately in one-way ANOVAs for soil type. In all cases, park was included as a block factor. Here, a significant soil effect indicates that the amount of a cover type differs between the two soil types.

The distribution of cover on each soil type was compared by using the transect data to calculate an evenness index for each transect. Pielou's J' was calculated according to the formula: $\mathrm{J}^{\prime}=\mathrm{H}^{\prime} / \mathrm{H}_{\max }$, where $\mathrm{H}^{\prime}$ is the ShannonWiener diversity index, $-\sum \mathrm{p}_{\mathrm{i}} \ln \mathrm{p}_{\mathrm{i}}$, and $\mathrm{H}_{\max }$ is richness $* \ln$ richness (Pielou, 1977). The J' index was then used as the dependent variable in a one-way ANOVA for soil type with park as a block. Here a significant soil effect indicates that evenness of cover differs according to soil type.

Cover distribution was also considered in terms of the patchiness of the habitat. By considering the total number of patches in each 10 meter transect, the 
variation in number of patches could be compared between soil types in a oneway ANOVA. The effect of the park was included as a block in this analysis as in all the others. For this analysis, a significant soil effect indicates that patchiness differs between soil types.

A factorial design in which the parks were the basic replicate was used for the analysis of data from the study. Edgewood and Santa Teresa parks are a straight line distance of $45 \mathrm{~km}$ apart and the slopes and aspects of the study sites in the parks differ. Thus, it was felt that the geographic location could be a significant source of variation. To control for such variation, park was included as a block in all of the factorial analyses. The serpentine and nonserpentine habitats looked quite different to the human eye and differences between the habitats were certainly expected. To insure that the statistical tests worked against the investigator's bias and to avoid Type I errors, the alpha level for the statistical analyses was set conservatively at 0.025 . Optimal sample size was calculated from literature and preliminary field data according to the procedure outlined by Bros and Cowell (Bros and Cowell, 1987) and was found to fall in the range of 6 to 10 samples. Eight to ten trench samples and six transect samples were taken from each study site. Trench samples were taken in June of 1991 and February through May of 1992. The transect samples were taken in June of 1992. Small sample size meant that variation was often high. In cases where data failed tests for homoscedasticity of variance after an appropriate transform, the data were ranked and the ranks were used as the dependent variable in statistical procedures (Conover, 1980). Using ranked data rather than raw data results in a test which will detect fewer differences in the data(Zar, 1984). 


\section{RESULTS}

Soil chemistry versus plant chemistry

Comparison of plant and soil chemistry by canonical correlation yielded five significant pairs for each soil type $(p<0.025)$. Nonserpentine soil showed three significant aboveground pairs and two significant belowground pairs. Serpentine soil showed the opposite pattern. The first canonical pairs for each plant tissue and soil type combination were representative of the correlation patterns seen in the other canonical pairs, and are reported below.

For aboveground plant chemistry, the primary canonical correlation with nonserpentine soil chemistry is illustrated in Figure 1A. The canonical loadings for soil values (Table 1) show that low soil scores on the $x$-axis are characterized by low magnesium but high levels of potassium, phosphorus, calcium and nitrogen. High soil scores indicate the reverse pattern. Plant canonical loadings (Table 1) show that low plant scores on the $y$-axis indicate low nitrogen, potassium, phosphorus, and calcium, but high magnesium. High plant scores indicate the reverse pattern. As the proportion of soil magnesium to the other soil elements increases, the proportion of plant magnesium to the other plant elements also increases. The graph also shows the effect of geographic location by a separation of the points for Edgewood Park from those for Santa Teresa Park.

The primary canonical correlation for aboveground plant chemistry and serpentine soil is illustrated in Figure 1B. The canonical loadings for the soil values (Table 1) indicate that low soil scores are characterized by low nitrogen, 
phosphorus and magnesium, and high calcium. High soil scores are seen when the reverse pattern is present. Plant loadings (Table 1) show that low plant scores result when phosphorus and potassium are low. When plant phosphorus and potassium are high, the plant canonical scores are also high. As the proportion between soil nitrogen, phosphorus, and magnesium, and soil calcium increases, the amount of phosphorus and potassium in aboveground plant tissues decreases.

For belowground plant tissue chemistry, the primary canonical correlation with nonserpentine soil chemistry is illustrated in Figure 2A. The loadings in Table 1 indicate that low soil scores occur when soil magnesium is low and soil potassium, phosphorus, calcium, and nitrogen are high. High soil canonical scores result when the opposite pattern occurs. Plant canonical loadings (Table 1) show that plant scores are low when plant nitrogen, phosphorus, calcium, and potassium are low and plant magnesium is high. When plant scores are high the pattern is reversed. As the proportion of soil magnesium relative to the other soil elements increases, the proportion of plant magnesium relative to the other plant elements also increases. The belowground correlations also show the same geographic location effect as the aboveground nonserpentine correlations. Points for Edgewood Park samples are separated from the points for Santa Teresa Park.

The primary canonical correlation for belowground plant chemistry and serpentine soil chemistry is illustrated in Figure 2B. Soil canonical loadings (Table 1) show that low soil scores are the result of high soil magnesium. High soil scores occur when soil magnesium is low. Belowground plant loadings (Table 1) indicate that plant scores are low when plant phosphorus and 
potassium are low and plant calcium and magnesium are high. High plant scores are seen when the pattern is reversed. As soil magnesium decreases, plant calcium and magnesium decrease, while plant phosphorus and potassium increase. This is the only time that magnesium and calcium are seen to vary directly in either plant tissues or soils.

The general pattern that emerges from the canonical correlations is that the abundance of elements in plant tissue increases as the abundance of soil elements increases with some interesting exceptions. Magnesium and calcium are inversely correlated in both plant tissues and soil, except for the belowground-serpentine pair. The one exception to the pattern of increasing abundance in plants when soil abundance increased was found in the aboveground canonical pair for serpentine soil. In that case plant phosphorus and potassium were high when soil nitrogen, phosphorus, and magnesium were low. 
Table 1: Canonical correlations and canonical loadings for comparisons of plant chemistry with soil chemistry. Loadings $\leq 0.3$ were not interpreted.

\begin{tabular}{ccccc}
\hline & \multicolumn{2}{c}{ Nonserpentine Soil } & Serpentine Soil \\
\hline & & & & \\
& $\begin{array}{c}\text { Aboveground } \\
\text { Pair 1 }\end{array}$ & $\begin{array}{c}\text { Belowground } \\
\text { Pair 1 }\end{array}$ & $\begin{array}{c}\text { Aboveground } \\
\text { Pair 1 }\end{array}$ & $\begin{array}{c}\text { Belowground } \\
\text { Pair 1 }\end{array}$ \\
& & & & \\
Correlations & 0.998 & 0.944 & 0.991 & 0.936 \\
Significance & $p<0.001$ & $\mathrm{p}<0.001$ & $\mathrm{p}<0.001$ & $\mathrm{p}<0.001$ \\
Loadings & & & & \\
Soil Ca & -0.743 & -0.685 & -0.381 & 0.113 \\
Soil Mg & 0.931 & 0.919 & 0.373 & 0.766 \\
Soil N & -0.349 & -0.384 & 0.726 & -0.009 \\
Soil K & -0.806 & -0.870 & -0.041 & 0.124 \\
Soil P & -0.860 & -0.728 & 0.506 & 0.089 \\
& & & & \\
Plant Ca & 0.340 & 0.712 & -0.168 & -0.571 \\
Plant Mg & -0.561 & -0.704 & -0.305 & -0.464 \\
Plant N & 0.867 & 0.913 & 0.110 & 0.139 \\
Plant K & 0.860 & 0.524 & 0.647 & 0.496 \\
Plant P & 0.851 & 0.838 & 0.876 & 0.702 \\
\hline
\end{tabular}




\section{A. Nonserpentine Soil}

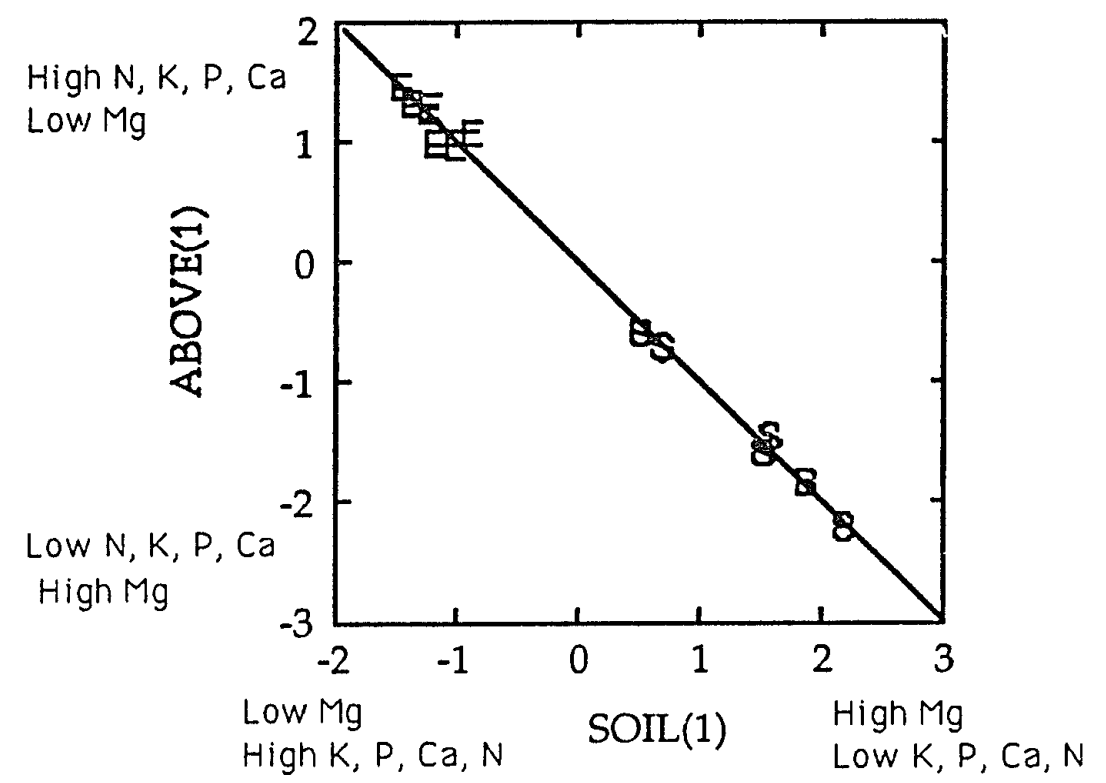

B. Serpentine Soil

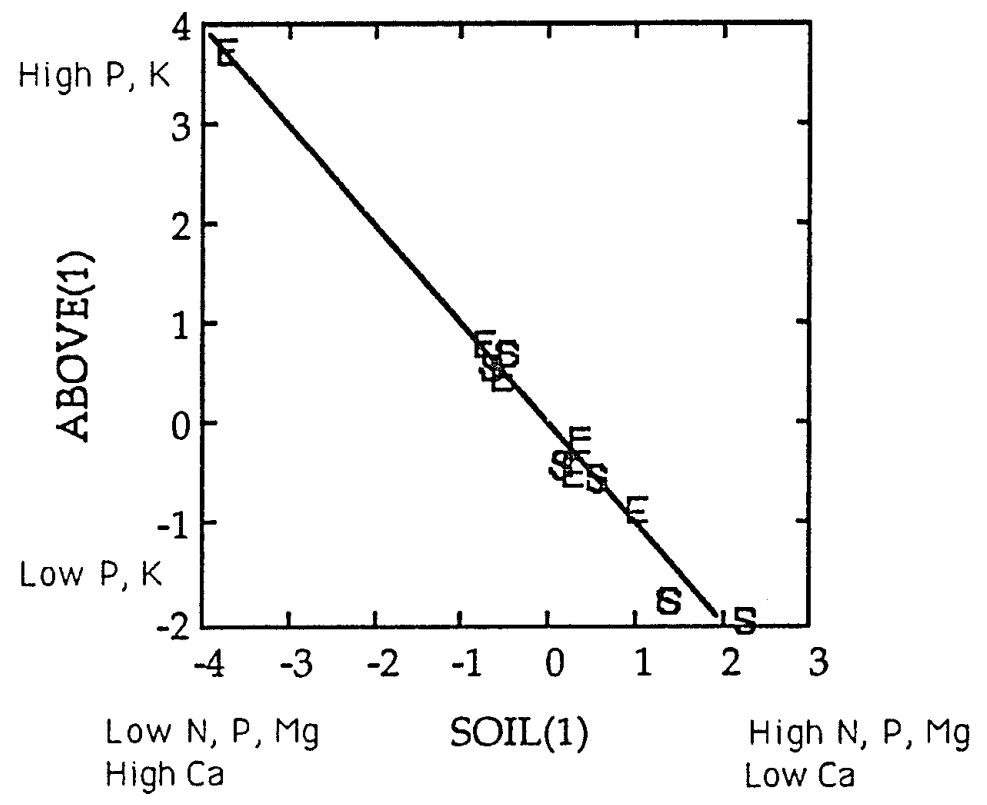

Figure 1. First significant canonical pairs comparing aboveground plant chemistry with soil chemistry for nonserpentine and serpentine soil types. $\mathrm{E}=$ Edgewood Park; $\mathrm{S}=$ Santa Teresa Park. 
A. Nonserpentine Soil

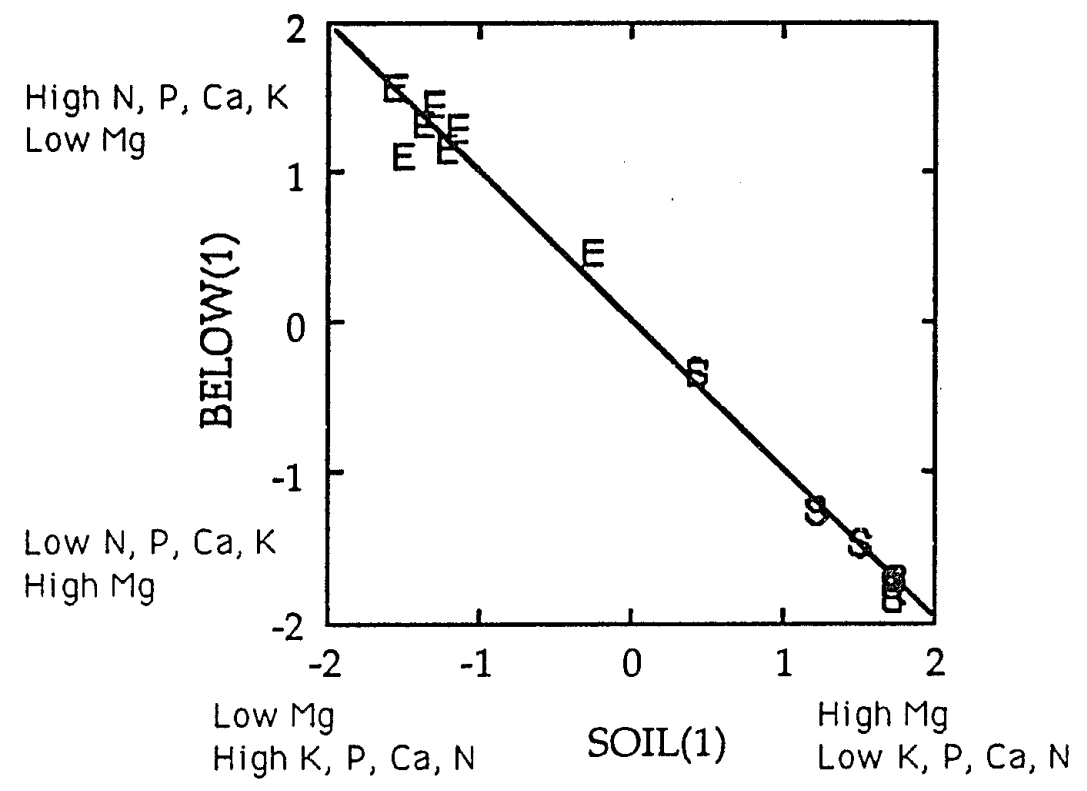

B. Serpentine Soil

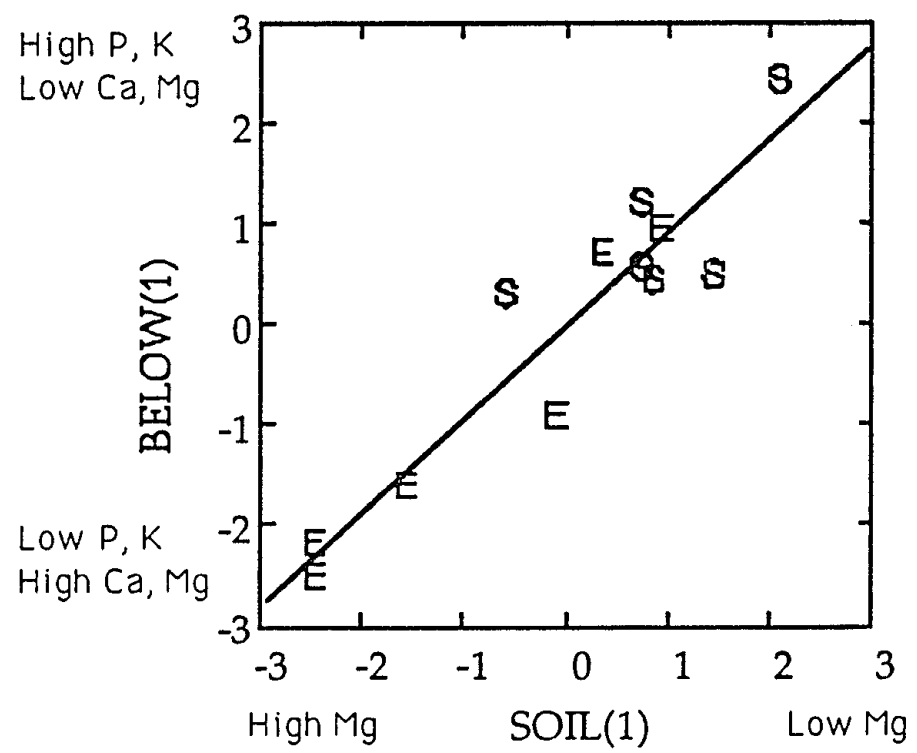

Figure 2. First significant canonical pairs comparing belowground plant chemistry with soil chemistry for nonserpentine and serpentine soil types. $\mathrm{E}=$ Edgewood Park; $\mathrm{S}=$ Santa Teresa Park. 
Biomass comparison

Evidence for a difference in food resources based on the plant biomass present on serpentine and nonserpentine soils is not clear. Results of the twoway ANOVA comparing plant biomass from the trench samples with respect to soil type and above- or belowground plant tissue location showed that there were no significant interactions nor were there differences in biomass resulting from tissue location (Table 2). The soil type effect would be considered significant at the 0.05 level, but not at the more conservative 0.025 chosen for the analysis. The p-value of 0.043 for the soil type effect would be considered barely significant under ordinary circumstances. In this case, analyzing the ranked data in the two-way ANOVA yielded a result with the ability to resolve a difference that is $9 \%$ of the grand ranked mean (42.5 ranks). Ranked data was used because the variation in the raw data was too great to meet assumptions for an ANOVA. Yet even the ranked data has a large variance relative to the ranked means (nonserpentine $=50.9$ ranks; serpentine $=34.1$ ranks; $\mathrm{s}^{2}=27.49$ ). The variation in the data coupled with small sample sizes makes the statistical evidence for a difference in biomass values weak. Biologically, the biomass available on all study sites seems to be sufficient to support pocket gopher populations. 
Table 2. Two-way ANOVA for soil type versus plant tissue location using ranked biomass. Park sampled is a block factor. Soil type levels are serpentine and nonserpentine. Tissue location levels are above- and belowground. Parks were Edgewood Park and Santa Teresa Park.

\begin{tabular}{lrrrr}
\hline \multicolumn{1}{c}{ Source } & DF & Mean Square & F-ratio & P \\
\hline Soil type & 1 & 5913.600 & 215.111 & 0.043 \\
Location & 1 & 8184.028 & 12.827 & 0.173 \\
Park & 1 & 1.886 & 0.006 & 0.952 \\
Location * Soil type & 1 & 606.864 & 1.844 & 0.404 \\
Location * Park & 1 & 638.077 & 1.938 & 0.397 \\
Soil type * Park & 1 & 27.491 & 0.084 & 0.821 \\
Location = Soil type * Park & 1 & 329.171 & 0.746 & 0.391 \\
Error & 76 & 441.436 & & \\
\hline
\end{tabular}




\section{Selective foraging}

Gopher feeding preference as measured by plant biomass differences between tunnel and nontunnel samples indicated a significant difference for dicots, but there were no other significant differences (Table 3). There were significantly more dicots in nontunnel samples than in tunnel samples (tunnel ranked mean $=31.2 \pm 18.23$; nontunnel ranked mean $=39.5 \pm 21.30, p=0.021$ ) indicating some gopher selection for dicot plants (Figure 3).

The evidence that gophers select for geophytes is weak (Table 3). The difference between tunnel and nontunnel means was barely significant $(\mathrm{p}=$ 0.047 ) at the usual alpha level of 0.05 and not significant at the more conservative 0.025 chosen for the study. The analysis of ranked data yielded results from the two-way ANOVA with the ability to resolve a difference at the 0.05 level that is $97 \%$ of the grand ranked mean ( 35.5 ranks).

\section{Comparisons of plant chemistry}

When food resources were considered in terms of plant chemistry, significant three-way interactions indicated that park, soil type and above-or belowground tissue location interact to affect the abundance of calcium and potassium in plant tissues(Table 4). These results reinforce the effect of geographic location seen in the correlations between plant and soil chemistry described above.

Plant calcium in all cases was greater in belowground tissues than in aboveground tissues (Figure 4). For serpentine soil, plant calcium levels were much greater at Edgewood Park than at Santa Teresa Park. The opposite was 
true at Santa Teresa; there, the nonserpentine plants contained more calcium. Calcium was more abundant in all plant tissues from nonserpentine soil than in the plants from serpentine soil. This difference was larger in the samples from Santa Teresa Park than samples from Edgewood Park.

Plant potassium content showed a different pattern of interactions with aboveground tissues containing more potassium than belowground tissues (Figure 5). Santa Teresa plants contain more potassium regardless of soil type or tissue location, but the difference was negligible for serpentine aboveground plants. Mean potassium content was about the same across soil types with the exception of Santa Teresa aboveground samples

In addition, the analysis of plant chemistry data indicated that plant tissues located aboveground contained more nitrogen than belowground tissues (Figure 6). Since ali of the samples were taken during the growing season, this result is not surprising (Ranked means: above $=31.8 \pm 13.33$; below $=20.0 \pm 14.2$; $\mathrm{p}=0.018$ ).

For magnesium, the lack of any significant differences is interesting because an analysis of soil chemistry showed a significant difference in soil magnesium content between the two parks. The ranked mean for soil magnesium content at Edgewood Park was greater than the mean for Santa Teresa Park (Ranked means: Edgewood $=17.8 \pm 7.72$, Santa Teresa $=12.0 \pm 8.56$, $\mathrm{p}<0.001)$. In addition the correlations between plant and soil magnesium values were strong in the canonical pairs. 
Table 3. Two-way ANOVAs for individual plant categories. The factors were soil type versus tunnel sample with park as a block. Data are ranked biomass. Soil type levels are serpentine and nonserpentine. Tunnel levels are tunnel sample and nontunnel sample. Parks were Edgewood Park and Santa Teresa Park.

\begin{tabular}{|c|c|c|c|c|}
\hline Source & DF & Mean Square & F-ratio & $\mathrm{p}$ \\
\hline \multicolumn{5}{|l|}{ Grass } \\
\hline Soil Type & 1 & 5862.781 & 28.931 & 0.117 \\
\hline Tunnel & 1 & 38.046 & 0.034 & 0.884 \\
\hline Park & 1 & 1617.043 & 36.598 & 0.079 \\
\hline Soil* Park & 1 & 202.647 & 7.970 & 0.217 \\
\hline Tunnel*Park & 1 & 1126.238 & 44.294 & 0.095 \\
\hline Soil= Tunnel & 1 & 7.952 & 0.313 & 0.675 \\
\hline Soil*Tunnel*Park & 1 & 25.426 & 0.079 & 0.779 \\
\hline Error & 62 & 321.262 & & \\
\hline \multicolumn{5}{|l|}{ Dicot } \\
\hline Soil Type & 1 & 2882.331 & 77.308 & 0.072 \\
\hline Tunnel & 1 & 1097.653 & 882.005 & 0.021 \\
\hline Park & 1 & 8342.403 & 151.199 & 0.052 \\
\hline Soil* Park & 1 & 37.284 & 0.676 & 0.562 \\
\hline Tunnel*Park & 1 & 1.244 & 0.023 & 0.905 \\
\hline Soil:Tunnel & 1 & 46.459 & 0.842 & 0.527 \\
\hline Soil*Tunnel*Park & 1 & 55.175 & 0.219 & 0.641 \\
\hline Error & 62 & 215.683 & & \\
\hline \multicolumn{5}{|l|}{ Geophyte } \\
\hline Soil Type & 1 & 10850.752 & 5.499 & 0.257 \\
\hline Tunnel & 1 & 93.474 & 179.010 & 0.047 \\
\hline Park & 1 & 1428.662 & 46.745 & 0.092 \\
\hline Soil*Park & 1 & 1973.295 & 64.565 & 0.079 \\
\hline Tunnel*Park & 1 & 0.522 & 0.017 & 0.917 \\
\hline Soil*Tunnel & 1 & 253.421 & 8.292 & 0.213 \\
\hline Soil*Tunnel*Park & 1 & 30.563 & 0.159 & 0.692 \\
\hline Error & 62 & 192.47 & & \\
\hline
\end{tabular}




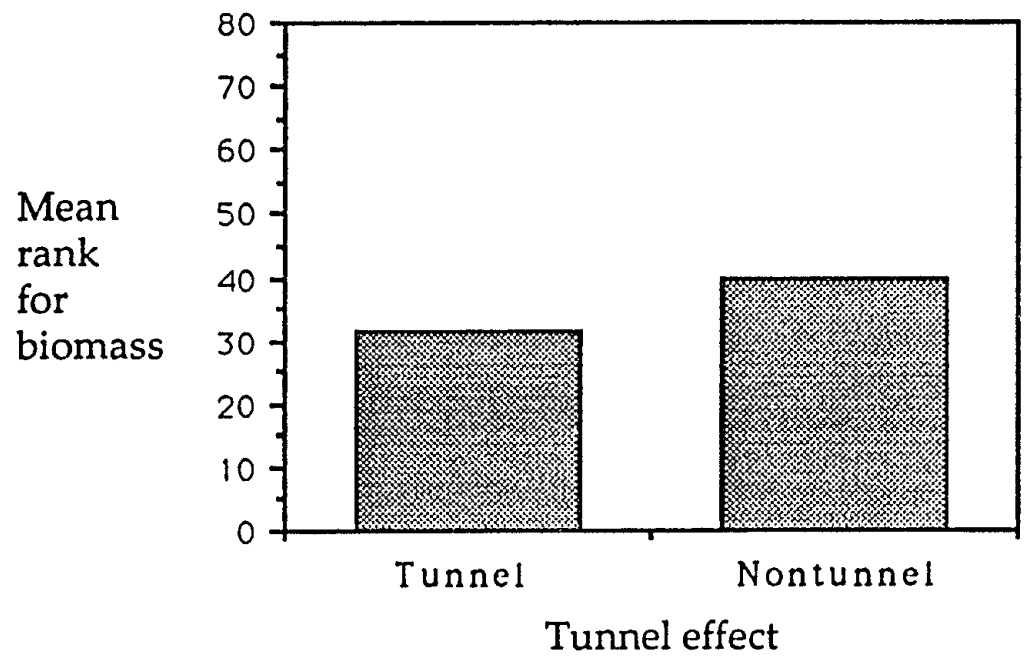

Figure 3. Dicot biomass: mean ranks for tunnel versus nontunnel samples. 
Table 4. Two-way ANOVAs for plant macronutrients. Data are arcsine transformed percent dry weight. Factors are soil type versus plant tissue location with park as a block factor.

\begin{tabular}{|c|c|c|c|c|}
\hline Source & $\overline{D F}$ & Mean Square & F-ratio & $\bar{P}$ \\
\hline \multicolumn{5}{|l|}{ Calcium } \\
\hline Soil type & 1 & 0.055 & 5.021 & 0.267 \\
\hline Location & 1 & 0.015 & 4.436 & 0.282 \\
\hline Park & 1 & 0.003 & 0.867 & 0.523 \\
\hline Soil Park & 1 & 0.011 & 3.710 & 0.305 \\
\hline Location * Park & 1 & 0.003 & 1.123 & 0.482 \\
\hline Soil $=$ Location & 1 & 0.011 & 3.642 & 0.307 \\
\hline Soil "Location * Park & 1 & 0.003 & 6.761 & 0.012 \\
\hline Error & 48 & 0.000 & & \\
\hline \multicolumn{5}{|l|}{ Magnesium } \\
\hline Soil type & 1 & 0.014 & 53.950 & 0.089 \\
\hline Location & 1 & 0.009 & 14.802 & 0.162 \\
\hline Park & 1 & 0.008 & 14.394 & 0.164 \\
\hline Soil - Park & 1 & 0.000 & 0.457 & 0.621 \\
\hline Location $*$ Park & 1 & 0.001 & 1.100 & 0.485 \\
\hline Soil - Location & 1 & 0.000 & 0.476 & 0.616 \\
\hline Soil " Location " Park & 1 & 0.001 & 3.084 & 0.085 \\
\hline Error & 48 & 0.000 & & \\
\hline \multicolumn{5}{|l|}{ Nitrogen } \\
\hline Soil type & 1 & 0.001 & 0.200 & 0.732 \\
\hline Location & 1 & 0.003 & 1240.450 & 0.018 \\
\hline Park & 1 & 0.002 & 18.462 & 0.146 \\
\hline Soil " Park & 1 & 0.005 & 55.110 & 0.085 \\
\hline Location $=$ Park & 1 & 0.000 & 0.023 & 0.904 \\
\hline Soil * Location & 1 & 0.000 & 0.701 & 0.556 \\
\hline Soil * Location * Park & 1 & 0.000 & 0.579 & 0.451 \\
\hline Error & 43 & 0.000 & & \\
\hline \multicolumn{5}{|l|}{ Phosphorus } \\
\hline Soil type & 1 & 0.001 & 1.309 & 0.457 \\
\hline Location & 1 & 0.000 & 14.459 & 0.164 \\
\hline Park & 1 & 0.001 & 108.728 & 0.061 \\
\hline Soil * Park & 1 & 0.001 & 64.728 & 0.079 \\
\hline Location $*$ Park & 1 & 0.000 & 3.012 & 0.333 \\
\hline Soil * Location & 1 & 0.000 & 2.782 & 0.344 \\
\hline Soil " Location * Park & 1 & 0.000 & 0.282 & 0.598 \\
\hline Error & 48 & 0.000 & & \\
\hline \multicolumn{5}{|l|}{ Potassium } \\
\hline Soil type & 1 & 0.002 & 0.542 & 0.596 \\
\hline Location & 1 & 0.012 & 41.106 & 0.099 \\
\hline Park & 1 & 0.007 & 3.851 & 0.300 \\
\hline Soil Park & 1 & 0.003 & 1.683 & 0.418 \\
\hline Location Park & 1 & 0.000 & 0.163 & 0.756 \\
\hline Soil Location & 1 & 0.001 & 0.566 & 0.589 \\
\hline Soil Location $=$ Park & 1 & 0.002 & 6.179 & 0.016 \\
\hline Error & 48 & 0.000 & & \\
\hline
\end{tabular}




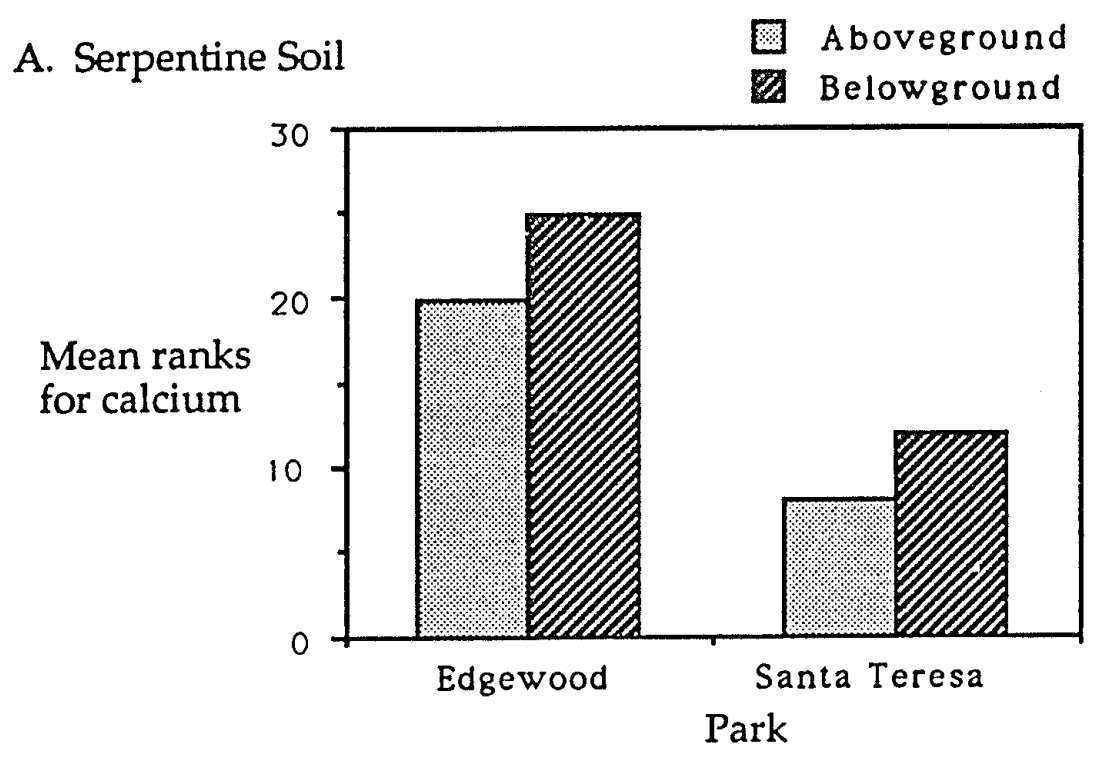

B. Nonserpentine Soil

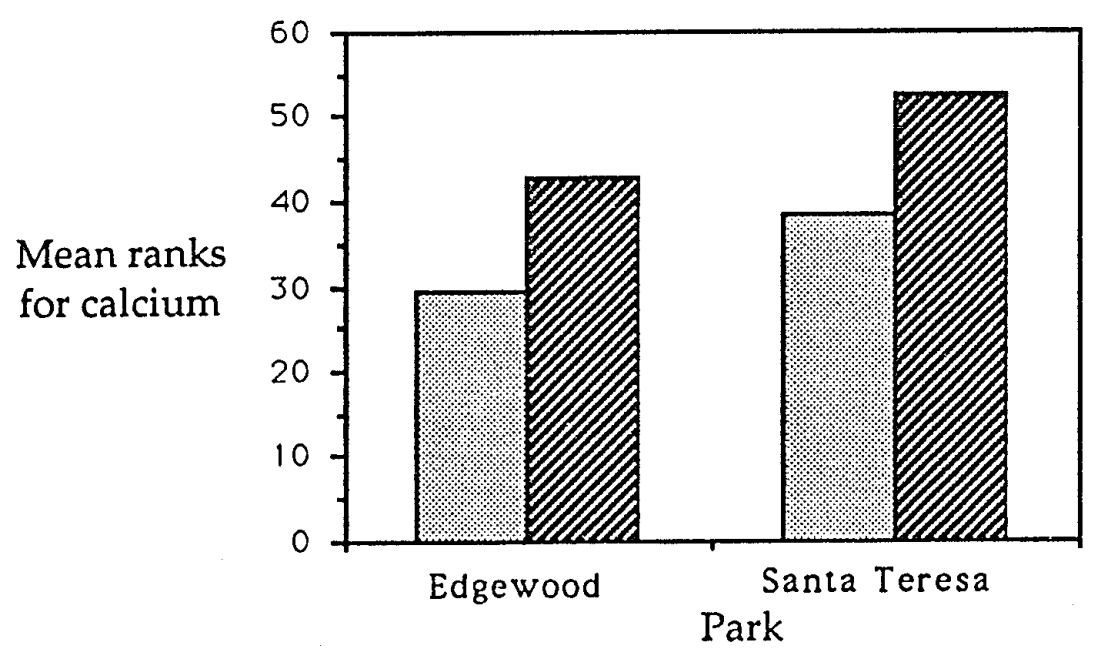

Figure 4. Plant calcium: comparison of mean ranks for significant three-way interaction, Soil * Location * Park. Soil type levels are serpentine and nonserpentine. Plant tissue location levels are above- and belowground. Park sampled was a block and included Edgewood Park and Santa Teresa Park. 
A. Serpentine Soil

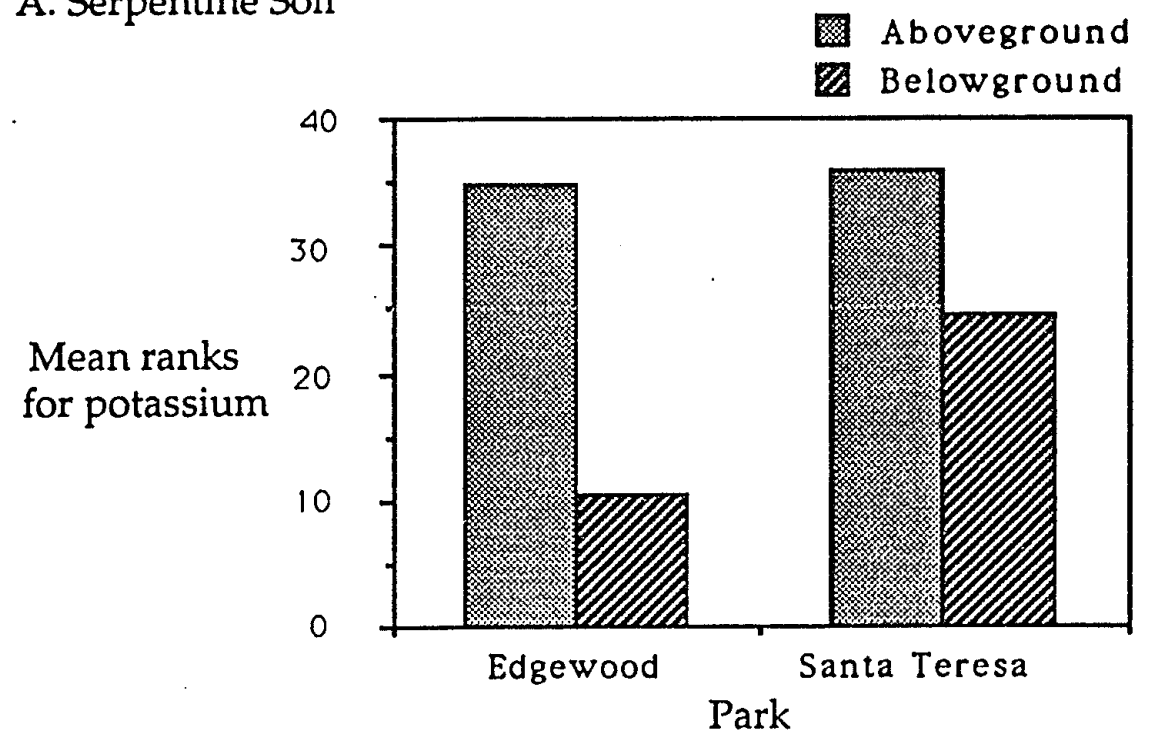

B. Nonserpentine Soil

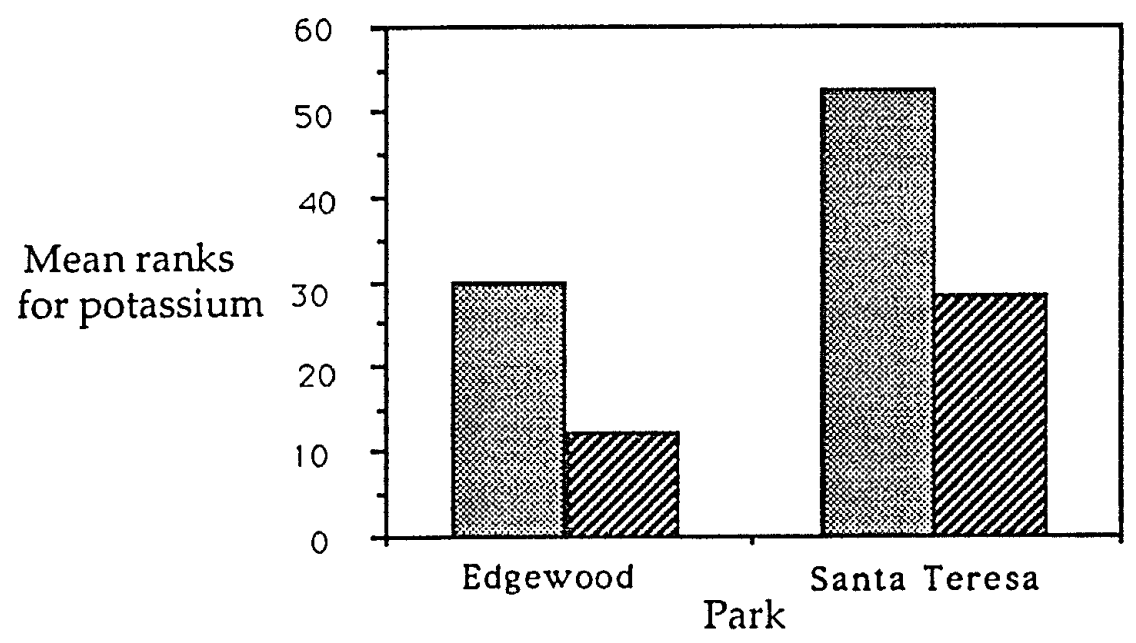

Figure 5. Plant potassium: comparison of mean ranks for significant three-way interaction, Soil * Location * Park. Soil type levels are serpentine and nonserpentine. Plant tissue location levels are above- and belowground. Park sampled was a block and included Edgewood Park and Santa Teresa Park. 


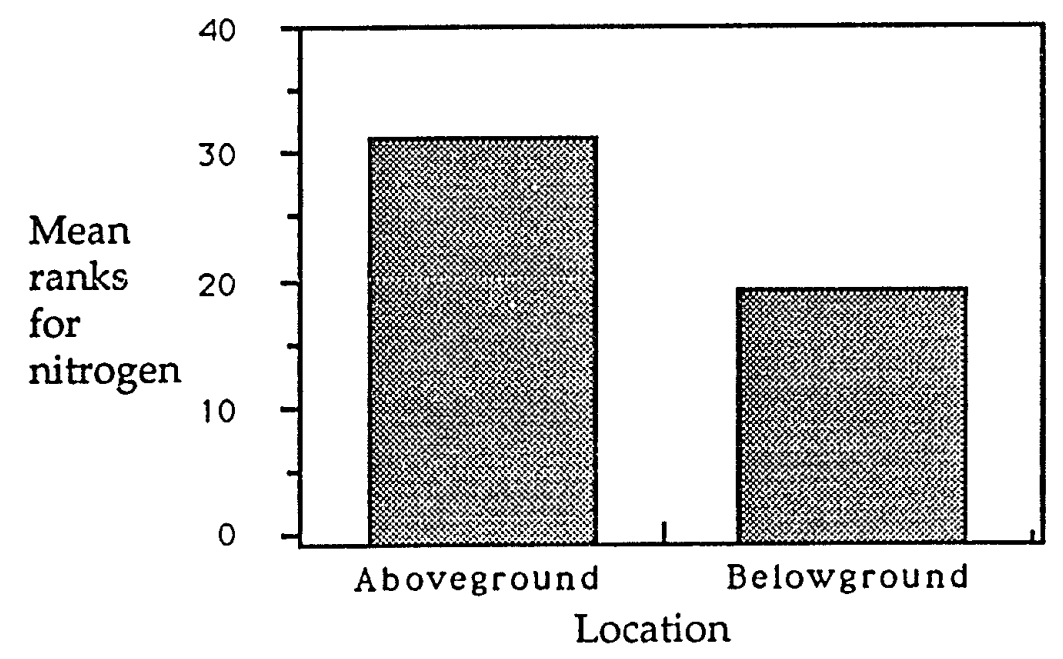

Figure 6. Plant nitrogen: mean ranks for plant tissues located aboveground versus belowground tissues. 


\section{Cover diversity}

The proportions of the cover types varied both with park and soil type (Table 5). The significant interaction term for cover times soil indicates that the apportionment of cover types is determined by the soil type. Serpentine soil had larger patches of cover than nonserpentine soil. Nonserpentine soil seemed to be dominated by large patches of grass (Figure 7).

The park sampled also determined the apportionment of cover types as indicated by the significant park-cover interaction term (Table 5). The picture of Santa Teresa Park that emerges from this analysis is of an area dominated by grass with relatively equal smaller patches of everything else. (Figure 8 ) This contrasts with Edgewood Park where grass and dicots seem to share the dominance. Much of the difference between the parks can be ascribed to the fact that Edgewood had significantly more dicots ( Ranked means: Edgewood = 83.3 $\pm 23.54 ;$ Santa Teresa $=58.3 \pm 21.22 ; \mathrm{p}=0.002)$, and Santa Teresa had significantly more rocks (Ranked means: Santa Teresa $=47.5 \pm 26.26 ;$ Edgewcod $=23.6 \pm$ $13.79 ; \mathrm{p}=0.013)$.

It appears from Table 5 that the single factor, cover type, was also significant. However, because the interaction between cover type and park is significant, the analysis cannot separate the effects of the interaction from the effects of the single factor. Thus the single factor must be ignored. 
Table 5. Two-Way ANOVA for cover type versus soil type with park as a block using ranked percent cover. Cover type levels were grass, dicot, bare ground, rock, and gopher mound. Soil type levels were serpentine and nonserpentine. Parks sampled were Edgewood Park and Santa Teresa Park.

\begin{tabular}{lrrrr}
\hline \multicolumn{1}{c}{ Source } & DF & Mean Square & F-ratio & P \\
\hline Cover Type & 4 & 20142.964 & 10.574 & 0.021 \\
Soil Type & 1 & 6992.133 & 93228.444 & 0.002 \\
Park & 1 & 243.675 & 0.756 & 0.387 \\
Cover * Park & 4 & 1904.972 & 5.911 & 0.000 \\
Soil * Park & 1 & 0.075 & 0.000 & 0.988 \\
Cover * Soil & 4 & 3123.743 & 9.651 & 0.025 \\
Cover * Soil * Park & 4 & 323.664 & 1.004 & 0.409 \\
Error & 100 & 322.267 & & \\
\hline
\end{tabular}




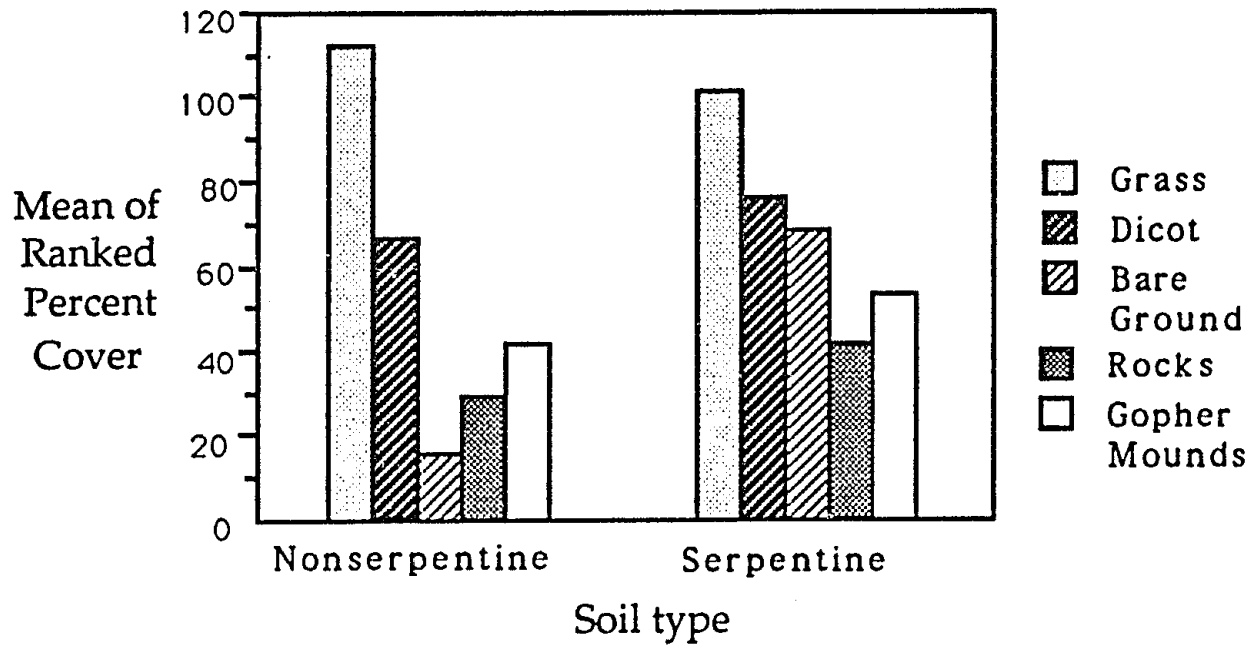

Figure 7. Percent Cover: mean ranks for significant Cover Type * Soil interaction. Cover type levels are grass, dicot, bare ground, rock, and gopher mound. Soil type levels are serpentine and nonserpentine.

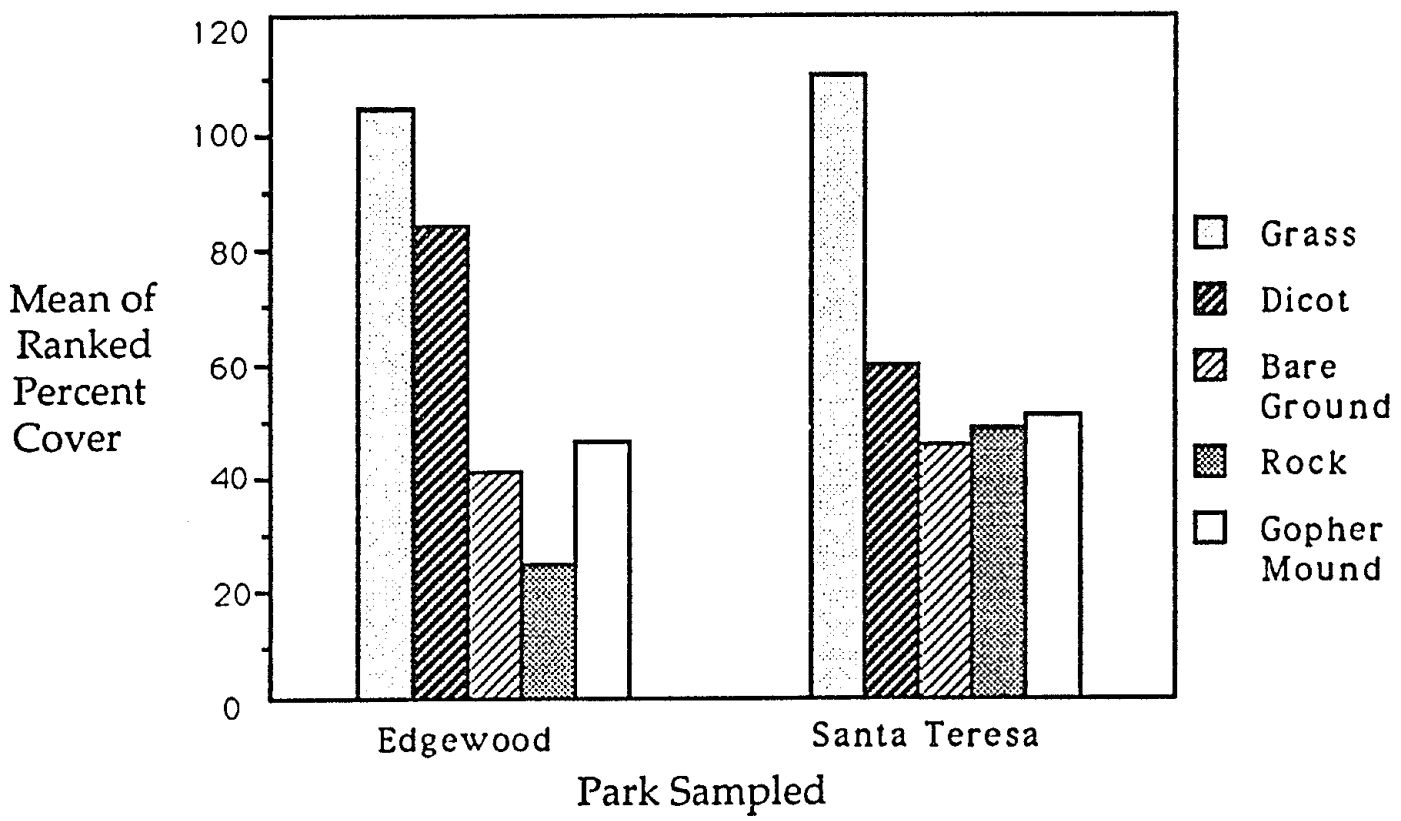

Figure 8. Percent Cover: mean ranks for significant Cover Type * Park interaction. Cover type levels are grass, dicot, bare ground, rock, and gopher mound. Parks sampled were Edgewood Park and Santa Teresa Park. 
The comparison of Pielou's J' evenness index showed that cover types were more evenly distributed at Edgewood Park than at Santa Teresa Park (Table 6). Pielou's J' includes both the abundance of individual cover types and the number of cover types present in a transect. Thus diversity and richness are combined into one measure. The greater ranked mean for J' at Edgewood Park (Edgewood $=0.222 \pm 0.095$; Santa Teresa $=0.145 \pm 0.040$ ) indicates that apportionment of cover patches was more even than at Santa Teresa. The number of cover patches, however, did not differ between the parks, nor between soil types . 
Table 6. One-Way ANOVAs for soil type with park as a block. Data are Pielou's J' and number of cover patches. Soil type levels are serpentine and nonserpentine. Parks sampled were Edgewood Park and Santa Teresa Park.

\begin{tabular}{lrrrr}
\hline \multicolumn{1}{c}{ Source } & DF & Mean Square & F-ratio & P \\
\hline Pielou's L' & & & & \\
$\quad$ Soil Type & 1 & 80.667 & 1.273 & 0.462 \\
Park & 1 & 376.042 & 11.949 & 0.002 \\
Soil*Park & 1 & 63.375 & 2.014 & 0.171 \\
Error & 20 & 31.471 & & \\
& & & & \\
Number of Patches & & & & \\
$\quad$ Soil Type & 1 & 600.000 & 25.000 & 0.844 \\
Park & 1 & 1.500 & 0.058 & 0.812 \\
Soil*Park & 1 & 24.000 & 0.926 & 0.347 \\
Error & 20 & 25.925 & & \\
\hline
\end{tabular}




\section{DISCUSSION}

Serpentine soil varies greatly from place to place in its chemical composition (Proctor and Woodell, 1975). This variation is caused by different parent materials and is complicated by differences in the geological history that brought serpentinitic outcrops to their present location. Thus, serpentine areas located near one another can be very different while still retaining those chemical characteristics which define them. The same can be said for the areas of nonserpentine origin which are associated with serpentine areas in time and space. They, too, will almost certainly vary in their chemical composition and geologic history. Therefore, geographic location of a study area becomes an important variable in any comparison within or between soil types. Hence, it would be incorrect to assume that variation in soil types was independent of where the sample was taken. In order to control for such geographic variation, a paired or block design must be used for analysis (Zar, 1984). In this study, the potential differences caused by soil type were usually overwhelmed by the variation resulting from the area (i.e., the park) sampled, and thus most differences found were attributed to the effect of geographic location.

The original proposal put forth by Proctor and Whitten (1971), that pocket gopher food resources found on serpentine soil somehow differed from nonserpentine food resources, assumed that their food resources were primarily belowground plant parts. Subsequent studies have show that Thomomys bottae includes a considerable amount of aboveground plant material in its diet. Gettinger (1984b) investigated whether free-living pocket gophers were able to maintain a balance between nitrogen intake and loss. He found that the animals 
showed seasonal variation not only by species eaten but also the parts of plants eaten, and in this way did maintain a positive nitrogen balance. Hunt (1989) found that the yearly diet of pocket gophers was greater than $70 \%$ from. aboveground plant parts. She also found that the portion of the gopher diet attributable to aboveground parts varied with the season and was highest during the rainy season and early spring. Plant samples in this study were taken during the growing season; thus, it was reasonable to assume that the pocket gophers on the study sites were making use of the aboveground portions of the available food resources.

Proctor and Whitten (1971) also specifically mentioned high magnesium levels in plants as a source of difference between soil types. They noted high magnesium levels for Brodiaea corms, which they felt were the principal cornponent of the late spring diets of the pocket gophers they sampled. But the results of the present study show that pocket gophers do not specialize on belowground plant parts, such as corms, nor on single species. When the chemistry of all the plant tissues from a site was measured, there were no differences in magnesium attributable to any of the factors considered.

The basic assumption examined by this study was that the chemical differences between serpentine and nonserpentine soils cause a difference in the food resources growing on the two soil types. This study indeed found that plant chemistry correlated well with soil chemistry. But while potential for chemical differences in the food resources certainly existed, no differences attributable solely to soil type were found. Instead, the differences found reflected interactions between soil types, geographic locations, and plant tissue 
locations that determined the abundance of calcium and phosphorus, and a difference between above- and belowground plant tissues for the abundance of nitrogen.

One could ask whether any of the food resources provide an adequate diet for pocket gophers. This study found that aboveground plant tissues contained significantly greater amounts of nitrogen than belowground tissues. There are few data on the subject of general dietary requirements for pocket gophers, but work has been done on nitrogen balance by Gettinger (1984b). His work showed that gophers were able to maintain a positive nitrogen balance when nitrogen influx exceeded 2300 to $2400 \mathrm{mg} \mathrm{N} / \mathrm{Kg} /$ day. For a pocket gopher weighing 150 $\mathrm{gm}$, this translates to 345 to $360 \mathrm{mg} \mathrm{N} /$ day. The aboveground plant biomass averaged 9.0 grams per sample with a mean nitrogen content of $.99 \%$, while the belowground biomass average was 5.1 grams per sample with $0.71 \%$ nitrogen for a sample area of .3 square meter. A $150 \mathrm{~g}$ pocket gopher eating all plants in an area of $1.2 \mathrm{~m}^{2}$ would be able to maintain a positive nitrogen balance on aboveground tissues alone. To do the same on only belowground tissues would require foraging over $19 \mathrm{~m}^{2}$. Eating both above- and belowground tissues would provide adequate nitrogen intake over an area of $0.9 \mathrm{~m}^{2}$, which equals a tunnel length of 1.2 meters. Vleck (1981) has calculated that a tunnel length of $1.2 \mathrm{~m}$ minimizes the cost of foraging versus the energy gained. Thus, one can argue that during the spring pocket gophers can meet their nitrogen requirements on either soil type in an energetically efficient manner.

The amount of food resources present can be used to determine whether pocket gophers can find enough resources to meet their needs. In this study the 
evidence is not clear whether a statistically significant biomass difference exists between soil types. However, one can still consider whether the biomass measured on the two sites differs in a way that impacts the biology of pocket gophers. Gettinger (1984a) calculated that Thomomys bottae requires a feeding rate of 119 grams $/ \mathrm{kg} /$ day for adequate energy supplies. A pocket gopher weighing 150 grams would need to harvest 41.25 grams per day. On nonserpentine soil, that amount could be harvested from an area of $1.4 \mathrm{~m}^{2}$, which equals a tunnel length of 1.8 meters. Serpentine soil would require harvesting an area of $2.3 \mathrm{~m}^{2}$, or 3 meters of tunnel. It appears that pocket gophers on serpentine soil must work $50 \%$ harder to harvest the same amount of plant material as those on nonserpentine soil. Thus, in the spring, pocket gophers will spend about the same amount of energy meeting their nitrogen and energy needs on nonserpentine soil. Pocket gophers living in serpentine soil, however, will spend more energy harvesting enough biomass to meet their energy needs than they need to spend acquiring nitrogen.

The distribution of plants and other cover can influence the ease with which a pocket gopher can obtain food efficiently. When the data from this study were examined for distribution patterns, it was found that the geographic location and soil type both determined plant distribution. Grasses dominated nonserpentine sites at both parks, and Santa Teresa Park in general. Grasses and dicots share dominance on both serpentine soil sites and at Edgewood Park in general. Patches of cover were more evenly distributed at Edgewood Park, thus the gophers at Edgewood have more varied food resources. Edgewood pocket gophers also were more likely to locate patches of dicots, which appear to be a favored food item in the spring. Pocket gophers at Santa Teresa had more grass 
in their diets, especially on the nonserpentine sites, and were less likely to come across a patch of dicots unless they were on the serpentine site.

Whether differences in food resources are determined by soil type is still an open question because the effect of geography was so strong in this study. Soil type plays a role in the distribution of calcium and phosphorus, but to what extent is unclear. Soil type also plays a role in the distribution of plants and cover, but again the extent of that role is unclear. The potential for a difference in plant biomass between soil types is tantalizing because the amount of biomass available affects the energetics of pocket gopher foraging. However, geographic location was also an important source of variation in analyses of plant chemistry and cover distribution.

While the potential for resource differences based on soil type certainly exists, it may not make any difference to pocket gophers. When compared to the food resources available to pocket gophers in nongrassland habitats, the grasslands on serpentine and nonserpentine soils may be more alike than different. Furthermore, Thomomys bottae is a widespread species in California, and clearly has the physiological tolerance to deal with many different habitats. In the end, the possibility of habitat differences that so fascinates human investigators may not be of any consequence to this adaptable mammal. 


\section{LITERATURE CITED}

Bros, W.E. and B. C. Cowell. 1987. A technique for optimizing sample size (replication). Journal of Experimental Marine Biology and Ecology, 114:63-. 71.

Bunnell, F. L. and A. S. Harestad. 1990. Activity budgets and body weight in mammals: How sloppy can mammals be? in Current Mammalogy, (Grenaways, H. H., ed.). 245-305 pp.

Conover, W. J. 1980. Practical nonparametric statistics. John Wiley \& Sons, Inc., New York.

Gettinger, R. D. 1984a. Energy and water metabolism of free-ranging pocket gophers, Thomomys bottae. Ecology, 65(3):740-751.

Gettinger, R. D. 1984b Seasonal patterns of nitrogen utilization by pocket gophers, Thomomys bottae. Comparative Biochemical Physiology, $78 \mathrm{~A}(4): 657-659$.

Huenneke, L. F., S. P. Hamburg, R. Koide, H. A. Mooney and P. M. Vitousek. 1990. Effects of soil resources on plant invasion and community structure in Californian serpentine grassland. Ecology, 71(2):478-491.

Hunt, J. 1989. Feeding ecology of Thomomys bottae sanctidiegi in a Mima mound and vernal pool habitat. Master of Science, San Diego State University.

Kruckeberg, A. R. 1954. The ecology of serpentine soils: III. Plant species in relation to serpentine soils. Ecology, 35(2):267-274.

Kruckeberg, A. R. 1984. California Serpentines: Flora, Vegetation, Geology, Soils, and Management Problems. University of California Press, Berkeley, 180 pp.

Patton, J. L. and P. V. Brylski. 1987. Pocket gophers in alfalfa fields: causes and consequences of habitat-related body size variation. American Naturalist, 130(4):493-506.

Pielou, E. C. 1977. Mathematical ecology. John Wiley \& Sons, New York.

Proctor, J. 1971. The plant ecology of serpentine: II. Plant response to serpentine soils. Journal of Ecology, 59:397-410. 
Proctor, J. and K. Whitten. 1971. A population of the Valley Pocket Gopher (Thomomys bottae) on a serpentine soil. American Midland Naturalist, 85(2):517-521.

Proctor, J. and S. R. J. Woodell. 1975. The ecology of serpentine soils. Advances in Ecological Research, 9:255-366.

Taiz, L. and E. Zeiger. 1991. Plant Physiology. Benjamin-Cummings, Redwood City, CA, 559 pp.

Vleck, D. 1981. Burrow structure and foraging costs in the fossorial rodent, Thomomys bottae. Oecologia, 49:391-396.

Walker, R. B. 1954. The ecology of serpentine soils: II. Factors affecting plant growth on serpentine soils. Ecology, 35(2):259-266.

Whittaker, R. H. 1954. The ecology of serpentine soils: IV. The vegetational response to serpentine soils. Ecology, 35(2):275-288.

Williams, L. R. and G. N. Cameron. 1986. Food habits and dietary preferences of Attwater's pocket gopher, Geomys attwateri. Journal of Mammalogy, 67(3):489-496.

Zar, J. H. 1984. Biostatistical Analysis. Prentice-Hall, Inc., Englewood Cliffs, NJ, $718 \mathrm{pp}$. 